University of Nebraska - Lincoln

DigitalCommons@University of Nebraska - Lincoln

$5-29-2003$

\title{
Use of $A_{3}$ Cytoplasm to Reduce Risk of Gene Flow through Sorghum Pollen
}

\author{
Jeffrey F. Pedersen \\ University of Nebraska-Lincoln, jpedersen1@unl.edu \\ D. B. Marx \\ University of Nebraska-Lincoln, david.marx@unl.edu \\ Deanna L. Funnell \\ University of Nebraska-Lincoln, dfunnell2@unl.edu
}

Follow this and additional works at: https://digitalcommons.unl.edu/plantpathpapers

Part of the Plant Pathology Commons

Pedersen, Jeffrey F.; Marx, D. B.; and Funnell, Deanna L., "Use of A 3 Cytoplasm to Reduce Risk of Gene Flow through Sorghum Pollen" (2003). Papers in Plant Pathology. 30.

https://digitalcommons.unl.edu/plantpathpapers/30

This Article is brought to you for free and open access by the Plant Pathology Department at DigitalCommons@University of Nebraska - Lincoln. It has been accepted for inclusion in Papers in Plant Pathology by an authorized administrator of DigitalCommons@University of Nebraska - Lincoln. 


\title{
Use of $A_{3}$ Cytoplasm to Reduce Risk of Gene Flow through Sorghum Pollen
}

\author{
J. F. Pedersen,* D. B. Marx, and D. L. Funnell
}

\begin{abstract}
A critical impediment to field testing and deployment of transgenic sorghum [Sorghum bicolor (L.) Moench] is the threat of gene flow to weedy relatives through pollen. A technique using sorghum with $A_{3}$ cytoplasmic male sterility to control transgene flow through pollen while using nontransgenic pollinators is described and an experiment was designed to evaluate the risk of viable pollen flow using $A_{3}$ hybrids under field conditions. Seed set under pollinating bags (an indicator of fertile pollen) was evaluated at the University of Nebraska Field Laboratory at Ithaca, NE, in 2001 and 2002 on selfed $F_{2}$ progeny grown from open pollinated seed of $12 F_{1}$ hybrids produced in $A_{1}$ and $A_{3}$ cytoplasm. The $F_{2}$ seed was produced in hybrid yield trials in 1997 and 1998 at Ithaca, NE. In each evaluation year, the experimental design was a split-split plot with seed production year the main plot factor, hybrid as the subplot factor, and cytoplasm as the sub-subplot factor. Cytoplasm effects were highly significant, with percent seed set on $A_{1} F_{2}$ individuals averaging $74 \%$, and on $A_{3} F_{2}$ individuals averaging $0.04 \%$. Upper confidence limits $(P=0.05)$ for percent seed set were $1.32 \%$ or less for the progeny from all $A_{3}$ hybrids. Polymerase chain reaction (PCR) analysis confirmed that four male fertile individuals (from a population of 1007) were detected with $A_{3}$ cytoplasm. These results support the hypothesis that gene flow through pollen can be severely restricted but not eliminated in sorghum by the use of $A_{3}$ cytoplasmic male sterility.
\end{abstract}

A Critical impediment to field testing and deployment of transgenic sorghum is the risk of gene flow to weedy relatives through pollen. Crop-to-weed gene flow has been documented from sorghum to johnsongrass [Sorghum halepense (L.) Pers.], a noxious weed, at distances of up to $100 \mathrm{~m}$ (Arriola and Ellstrand, 1996). Although the triploid progeny of johnsongrass $x$ sorghum hybrids would be expected to be sterile, viable seed production on johnsongrass $\times$ sorghum hybrids has been reported (Arriola and Ellstrand, 1997; HoangTang and Liang, 1988) and fitness of hybrid progeny found to be equivalent to johnsongrass (Arriola and Ellstrand, 1997), causing those authors to conclude that "a transgene that is either neutral or beneficial to johnsongrass would likely persist in populations growing in agricultural conditions under continued gene flow from the crop."

Shattercane [S. bicolor subsp. drummondii (Nees ex Steud.) de Wet \& Harlan], a noxious weed of economic importance to commercial corn (Zea mays L.), soybean [Glycine max (L.) Merrill], and sorghum production, crosses freely with cropped sorghum. Previous field re-

J.F. Pedersen and D.L. Funnell, USDA, ARS, NPA Wheat, Sorghum and Forage Research, Dep. of Agronomy, University of NebraskaLincoln, Lincoln, NE 68583-0937; D.B. Marx, Dep. of Biometry, University of Nebraska-Lincoln, Lincoln, NE 68583-0712. Joint contribution of the USDA-ARS and the University of Nebraska Agric. Exp. Stn. as Paper no. 13619, Journal Series, Nebraska Agric. Exp. Stn. Received 8 March 2002.*Corresponding author (jfp@unlserve. unl.edu).

Published in Crop Sci. 43:1506-1509 (2003). search at Ithaca, NE, involving sudangrass, a cultivated form of S. bicolor subsp. drummondii, showed natural outcrossing averaging 39 and $57 \%$ in each of two years (Pedersen et al., 1998). If similar outcrossing is present in shattercane, gene flow through pollen from cropped sorghum to shattercane populations could be rapid.

The use of cytoplasmic male sterility to prevent the release of viable pollen from transgenic corn has been recently proposed by Feil et al. (in press). In their system, transgenic plants are male sterile and are grown in a mixture with fertile nontransgenic pollen donors. Additionally, exploiting male sterile:male fertile pollinator mixtures has already proven commercially successful for the production of high oil maize (Bergquist et al., 1998a) and high grain quality maize (Bergquist et al., 1998b). It appears that exploiting male sterile:male fertile pollinator mixtures to reduce the threat of transgene flow through pollen in sorghum could be commercially viable.

Nearly all commercial sorghum hybrids are currently produced by means of $\mathrm{A}_{1}$ cytoplasmic male sterile seed parents. This is at least partially due to the availability of many lines known to restore fertility (R-lines) when crossed to $\mathrm{A}_{1}$ cytoplasm (Bosques-Vega et al., 1989; Torres-Cardona et al., 1990). Since many lines are known to restore fertility in $\mathrm{A}_{1}$ cytoplasm, the probability of male fertile volunteer escapes following sorghum harvest is also high. In a system such as that proposed by Feil et al. (in press), the risk of transgene flow from fertile volunteer escapes is unacceptable for sorghum hybrids based on $\mathrm{A}_{1}$ male sterile cytoplasm. Even if lines known to maintain $\mathrm{A}_{1}$ cytoplasmic male sterility ( $B_{1}$-lines) were to be used as pollinators in the mixture, stray pollen from shattercane or neighboring sorghum fields with the capacity to restore fertility to $\mathrm{A}_{1}$ cytoplasmic male steriles could be expected to pollinate some of the transgenic sorghum females and introduce male fertile transgenic plants into the population of volunteer escaped plants.

Because of the near absence of lines capable of restoring fertility to $\mathrm{A}_{3}$ cytoplasmic male sterile lines (Bosques-Vega et al., 1989; Torres-Cardona et al., 1990), it should be possible to greatly reduce the risk of gene flow through pollen from commercial transgenic sorghum to weedy relatives, or commercial nontransgenic sorghum, by adapting the technique proposed by Feil et al. (in press) to $\mathrm{A}_{3}$ cytoplasmic male sterile sorghum.

Such an adaptation would include the following steps. The transgenic line is converted to an $\mathrm{A}_{3}$ male-sterile cytoplasm line by backcrossing under strict isolation, preferably in a greenhouse or growth chamber to reduce the risk of escape of viable transgenic pollen. Once converted to an $\mathrm{A}_{3}$ line, seed increase would be performed in the field following the normal procedure for A/B-lines (Quinby and Schertz, 1970) with intensive 
cultural control of volunteer seedlings, including cultivation, crop rotation or fallowing in subsequent cropping seasons, and use of herbicides with activity against sorghum. No transgenic pollen should be viable, and most transgenic seed falling to the ground would not survive intense agricultural culture. Any volunteer plants escaping cultural control should be male sterile and would be rapidly lost from the gene pool. Production of hybrid seed would be accomplished with known heterotic combinations and the same restrictions as for seed increase. In commercial grain production fields, a pollen source would be provided by mechanically mixing a small proportion $(10 \%)$ of nontransgenic seed with the male sterile transgenic seed before planting. As above, any volunteer transgenic plants escaping cultural control should be male sterile and would be rapidly lost from the gene pool from under intensive cultural control.

Although the efficacy of male sterilization by means of $\mathrm{A}_{3}$ cytoplasm and the near absence of lines known to restore fertility are well established, the risk of fertility restoration by random pollen under field conditions has not been assessed. The objective of this study was to measure the frequency of fertility restoration in seed from $\mathrm{A}_{3}$ cytoplasmic male sterile hybrids produced under field conditions.

\section{MATERIALS AND METHODS}

\section{Open Pollination of $F_{\mathbf{1}}$ Hybrids}

Twelve isocytoplasmic $\mathrm{F}_{1}$ hybrids were produced in $\mathrm{A}_{1}, \mathrm{~A}_{2}$, $A_{3}$, and $A_{4}$ cytoplasm $\left(A_{3}\right.$ hybrids shown, Table 1$)$ and grown in hybrid yield trials in 1997 and 1998 at the University of Nebraska Field Laboratory at Ithaca, NE (Sharpsburg silty clay loam [fine smectitic mesic Typic Agriudoll]). Plots were $7.6 \mathrm{~m}$ long, with two rows spaced $76 \mathrm{~cm}$ apart. The experimental design was a split plot with hybrid the main plot factor, cytoplasm the subplot factor, and was replicated four times. Planting dates were 22 May 1997 and 18 May 1998. Plots were fertilized with $112 \mathrm{~kg} \mathrm{ha}^{-1} \mathrm{~N}$ before planting. For weed control, propachlor [2-chloro- $N$-(1-methylethyl)- $N$-phenylacetamide] and atrazine [6-chloro- $n$-ethyl- $N$ '-(1-methylethyl)-1,3,5-triazine-2,4,diamine] were applied at 3.36 and $1.12 \mathrm{~kg} \mathrm{ha}^{-1}$, respectively, immediately after planting. No attempt was made to isolate the yield trial from exogenous pollen sources, which included diverse sorghum genotypes planted in the same experimental nursery and shattercane present in surrounding agricultural production fields. No supplemental irrigation was applied. Plots were harvested with a small-plot combine and subsamples of open pollinated seed were stored at $8^{\circ} \mathrm{C}$ until evaluated for self fertility in the next generation.

\section{Evaluation of $F_{\mathbf{2}}$ Progeny for Fertility}

$\mathrm{F}_{2}$ progeny from each $\mathrm{A}_{1}$ and $\mathrm{A}_{3}$ hybrid yield trial plot described above were planted 19 May 2001 and 21 May 2002 at Ithaca, NE. Agronomic culture, soil type, and plot arrangement were as described above, except plots consisted of a single $7.6 \mathrm{~m}$ long row. The main panicle from ten (occasionally 11) random $F_{2}$ individuals in each plot was covered with a pollinating bag before initiation of anthesis. Pollinating bags were inspected for integrity at plant maturity and removed. Percent seed set on individual panicles was visually estimated relative to a completely fertile panicle. Only panicles that
Table 1. Percent seed set on selfed $A_{3} F_{2}$ individuals from open pollinated $\mathbf{A}_{3} \mathbf{F}_{1}$ male sterile hybrids.

\begin{tabular}{|c|c|c|c|}
\hline Hybrid & $\begin{array}{c}\text { Lower } \\
\text { confidence limit } \\
(P=0.05)\end{array}$ & $\begin{array}{c}\text { Upper } \\
\text { confidence limit } \\
(P=0.05)\end{array}$ & $\begin{array}{c}\text { Mean } \\
(n=80)\end{array}$ \\
\hline & \multicolumn{3}{|c|}{$\%$ seed set on selfed $A_{3} F_{2}$ individuals } \\
\hline $\mathbf{A}_{3} \mathbf{T} \mathbf{3} 398 \nrightarrow \times$ ROKY10 & -0.22 & 0.70 & 0.03 \\
\hline $\mathbf{A}_{3} \mathbf{T} \times 398 \times 78-10603$ & -0.23 & & 0.01 \\
\hline $\mathbf{A}_{3} \mathbf{T} \times 398 \times$ RIA28 & -0.23 & 0.63 & 0.00 \\
\hline $\mathbf{A}_{3} \mathbf{K S 5 7} \times \mathbf{R O K Y 1 0}$ & -0.22 & 0.72 & 0.04 \\
\hline $\mathbf{A}_{3} \mathrm{KS} 57 \times \mathbf{7 8 - 1 0 6 0 3}$ & $-\mathbf{0 . 2 3}$ & 0.69 & 0.02 \\
\hline A3KS57 $\times$ RIA28 & -0.22 & 0.73 & 0.04 \\
\hline $\mathbf{A}_{3}$ Tx3042 $\times$ ROK & -0.21 & 0.79 & 0.06 \\
\hline $\mathbf{A}_{3} \mathbf{T} \times 3042 \times 78-10603$ & -0.25 & 0.56 & 0.03 \\
\hline A $_{3}$ Tx3042 $\times$ RIA 28 & -0.23 & 0.70 & 0.03 \\
\hline $\mathbf{A}_{3}$ Wheatland $\times$ ROKY10 & -0.24 & 0.59 & 0.01 \\
\hline $\mathbf{A}_{3}$ Wheatland $\times 78-10603$ & -0.14 & 1.32 & 0.26 \\
\hline $\mathbf{A}_{3}$ Wheatland $\times$ RIA28 & -0.20 & 0.85 & 0.08 \\
\hline $\mathbf{A}_{3}$ Hybrid Mean & $-\mathbf{0 . 1 9}$ & 0.56 & 0.04 \\
\hline
\end{tabular}

$\dagger$ Sources of parent lines: $\mathbf{A}_{3}$ Tx398 (Schertz, 1984); $\mathbf{A}_{3}$ KS57 = $\mathbf{A}_{3} \mathbf{N 1 8 2}$, $\mathbf{A}_{3} \mathbf{T x} 3042=\mathbf{A}_{3} \mathbf{N 1 8 5}, \mathbf{A}_{3}$ Wheatland $=\mathbf{A}_{3} \mathbf{N 1 8 8}$ (Pedersen and Toy, 1997); ROKY10 (Weibel et al., 1984); IA28 (Atkins, 1983); 78-10603 appears to be a selection of ROKY10 made at Mead, NE, from an unknown source in 1978.

had remained covered throughout the pollination period were included in the data set.

The data were analyzed with a generalized mixed linear model with SAS's macro GLIMMIX (Littell et al., 1996). This approach assumes a binomial response for the data and allows for random effects in the model. After combining subsamples, data were analyzed as a split-split plot with year of $F_{2}$ seed production as the main plot factor, hybrid as the subplot factor and cytoplasm as the sub-subplot factor. Year of fertility evaluation was considered random variable and was tested with residual error. Glimmix uses a LOGIT transformation when binomial data are being analyzed. The estimated LOGIT transformed values for each of the $\mathrm{A}_{3}$ hybrid means and the estimated stand errors were used to calculate the confidence limits. The resulting confidence intervals were then back transformed for reporting and discussion.

\section{PCR Analysis}

Fertile $A_{3} F_{2}$ progeny grown in 2002 were examined using PCR analysis to confirm seed purity (as indicated by $\mathrm{A}_{3}$ cytoplasm). Selfed seeds from the fertile $A_{3} F_{2}$ progeny, and from $\mathrm{A}_{1}, \mathrm{~A}_{2}, \mathrm{~A}_{3}$, and $\mathrm{A}_{4}$ 'Wheatland' (Pedersen and Toy, 1997) were sowed in separate pots and grown in the greenhouse. One young leaf from each of 5 seedlings per line were removed, 12 to $19 \mathrm{~d}$ following planting, and frozen at $-20^{\circ} \mathrm{C}$. Leaves from a given line were combined and total DNA was extracted by means of the Nucleon Phytopure Kit (Amersham Biosciences, Piscataway, NJ). PCR primers DP143 and DP47, developed to span mitochondrial orf107 in IS1112C (Pring et al., 1998), the type member of the $S$. bicolor $\mathrm{A}_{3}$ group of male sterile cytoplasms, were utilized to indicate the presence of the marker for $\mathrm{A}_{3}$ male sterile cytoplasm (reviewed in Pring et al., 1999). Primers were produced by Invitrogen (Carlsbad, CA). PCR reactions were prepared by means of Amplitaq Gold PCR Master Mix (Applied Biosystems, Foster City, CA) and PCR was begun with a $5 \mathrm{~min}, 94^{\circ} \mathrm{C}$ hot-start followed by 30 amplification cycles of $30 \mathrm{~s}$ at $94^{\circ} \mathrm{C}, 60 \mathrm{~s}$ at $62^{\circ} \mathrm{C}$ and $60 \mathrm{~s}$ at $72^{\circ} \mathrm{C}$ and completed with a 7 min extension at $72^{\circ} \mathrm{C}$. Reactions were size fractionated in $2 \%(\mathrm{w} / \mathrm{v})$ agarose gels. Control DNAs from plant lines IS1112C and $\mathrm{B}_{3}$ Tx398 (fertility maintainer line) and from pHC104, containing orf107 (Tang et al., 1996), were generously provided by Daryl Pring. 


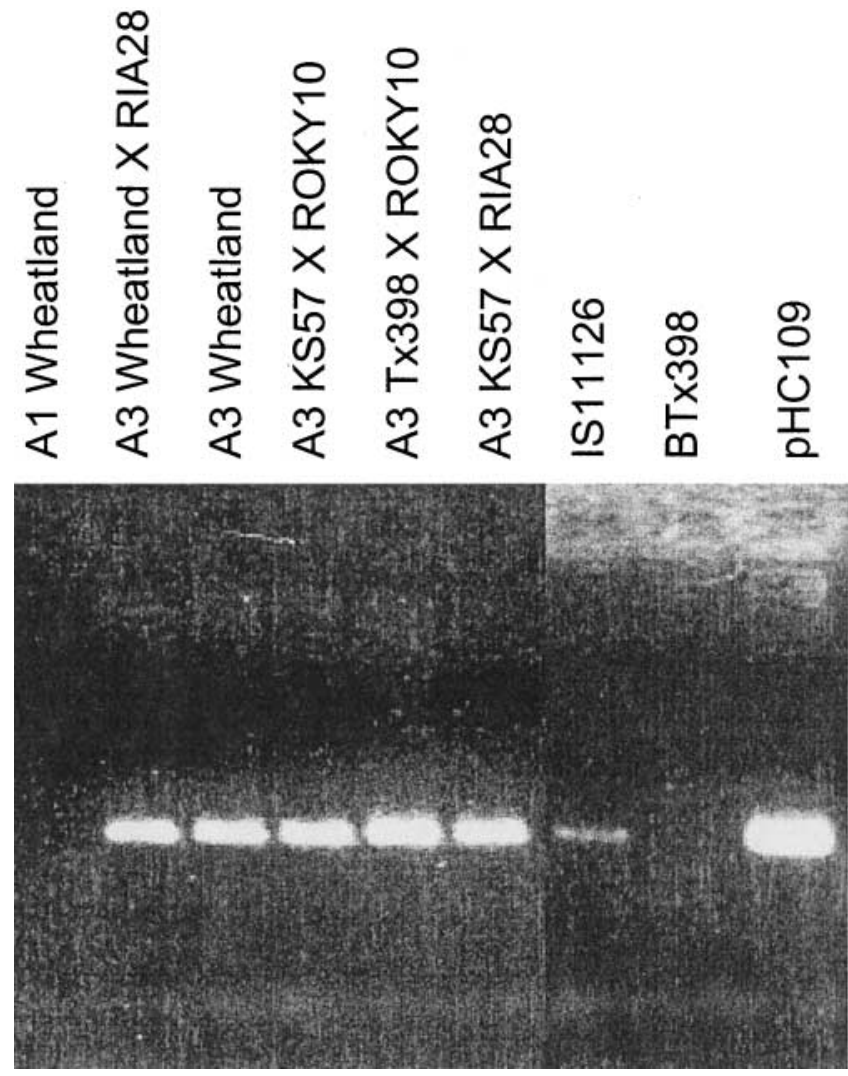

Fig. 1. PCR analysis of total DNA from fertile individuals with putatively $\mathbf{A}_{3}$ cytoplasm. PCR analysis was conducted on total DNA from fertile progeny lines, positive controls $\left(A_{3}\right.$ Wheatland and IS11126), negative controls ( $\mathbf{A}_{1}$ Wheatland and BTx398) as well as DNA of the plasmid containing mitochondrial orf107 (pHC109).

\section{RESULTS AND DISCUSSION \\ Evaluation of $F_{2}$ Progeny for Fertility}

Year of fertility evaluation and year of $\mathrm{F}_{2}$ seed production effects were not significant at $P=0.05$. Cytoplasm effects were highly significant $(P<0.0001)$, with percent seed set on selfed $\mathrm{A}_{1} \mathrm{~F}_{2}$ individuals averaging $74 \%$, and percent seed set on selfed $\mathrm{A}_{3} \mathrm{~F}_{2}$ individuals with averaging $0.04 \%$. Hybrid and hybrid $\times$ cytoplasm effects were highly significant $(P=0.0065$ and $P<0.0001$, respectively), but examination of the data leads us to believe that the hybrid $\times$ cytoplasm interaction was due to hybrid differences in $\mathrm{A}_{1}$ cytoplasm. $\mathrm{F}_{2}$ individuals from $\mathrm{A}_{1}$ hybrids were necessarily included in the study as positive checks to establish that substantial fertility restoration occurred and was detected (data not shown).

Mean percent seed set for selfed individuals of $\mathrm{A}_{3} \mathrm{~F}_{2}$ hybrid families, and upper and lower confidence limits for each mean are shown in Table 1 . Average percent seed set approached zero for selfed $\mathrm{A}_{3} \mathrm{~F}_{2}$ progeny from all 12 hybrids (lower confidence limits $\leq-0.14, P=$ 0.05 ; upper confidence limits $\leq 1.32, P=0.05$ ). However, the incidence of individuals with the ability to set seed when selfed in most $A_{3} F_{2}$ hybrid families was indicative of viable pollen being produced by at least some of these individuals.

Examination of the raw data from 2001 revealed that nine of $946 \mathrm{~A}_{3} \mathrm{~F}_{2}$ individuals examined set seed and had
90 to $100 \%$ seed set, thus ruling out error due to bagging after a small number of stigmas were exerted. All other $\mathrm{A}_{3} \mathrm{~F}_{2}$ individuals examined had no seed set. It was therefore hypothesized that infrequent, but observed, incomplete combine and planter clean-out between plots could have contributed to mechanical mixing of non$A_{3}$ seed with the $A_{3}$ seed. Such contaminating seed could be misinterpreted as viable pollen being produced by a very low percentage of $A_{3}$ individuals. Seed was not harvested from the nine fertile individuals exhibiting seed set in 2001.

The fertility evaluation experiment was therefore repeated in 2002 and selfed seed from fertile $A_{3} F_{2}$ individuals harvested for determination of cytoplasm. Examination of the raw data from 2002 revealed that 20 of $1007 \mathrm{~A}_{3} \mathrm{~F}_{2}$ individuals set seed.

\section{PCR Analysis of 20 Fertile Putatively $\mathbf{A}_{3}$ Individuals}

Four of the 20 self fertile $A_{3} F_{2}$ progeny lines contained plants carrying the mitochondrial orf107 marker for $\mathrm{A}_{3}$ male sterile cytoplasm (Fig. 1). The 16 self fertile individuals not carrying the mitochondrial orf107 marker for $\mathrm{A}_{3}$ male sterile cytoplasm are assumed to have arisen from contaminant non- $\mathrm{A}_{3}$ seed. PCR analysis was repeated on the four lines with the $A_{3}$ cytoplasm using a newly prepared DNA to ascertain that these results were not due to DNA contamination, and the results were identical (data not shown). Three of the four selfed confirmed $\mathrm{A}_{3} \mathrm{~F}_{2}$ individuals exhibited high percent seed set (from 90-100\%) indicating that these individuals were not incorrectly classified as fertile because of bagging after a small number of stigmas were exerted. The fourth confirmed $\mathrm{A}_{3} \mathrm{~F}_{2}$ individual had low percent seed set $(5 \%)$ which could possibly be attributed to bagging error.

Conservatively, in 2002 restoration of fertility in $\mathrm{A}_{3}$ cytoplasm could have occurred independently in 4 of 1007 lines, or at a rate of $0.4 \%$. This observation is not without precedent. Unexplained low levels of fertility in progeny of $\mathrm{A}_{3} \mathrm{Tx} 398$ pollinated with sudangrass pollen were observed in previous research at our location (Pedersen and Toy, 1997). Recovered restoration capability to $\mathrm{A}_{3}$ male sterile cytoplasm has similarly been observed by in bulks of NP28 and NP35 sudangrass (D.R. Pring, personal communication, 2003). We are continuing experimentation with these four self fertile lines perhaps to establish reasons for these unexpected results.

\section{CONCLUSIONS}

Additional research investigating associated risks and benefits of adaptation of the technique proposed by Feil et al. (in press) to sorghum using $\mathrm{A}_{3}$ male sterility will be necessary. The unexplained apparent fertility restoration in four of $1007 \mathrm{~A}_{3}$ lines needs to be understood to assess better the risks of gene flow through pollen from such plants. Large scale use of $\mathrm{A}_{3}$ male sterile hybrid seed containing a small percentage of nontransgenic pollinators would also increase the risk of infection by sorghum ergot (Claviceps africana Frederickson, 
Mantle, and de Milliano) because of increased numbers of unfertilized stigma which are the infection site of the pathogen (Frederickson et al., 1991). Potential benefits in addition to reducing the risk of transgene flow through pollen include in-field refugia provided by the nontransgenic pollinators used in such a system, and the opportunity to capture xenia effects in resulting grain.

The results from this study support the hypothesis that gene flow through pollen can be severely restricted in sorghum by adaptation of the technique proposed by Feil et al. (in press) to $\mathrm{A}_{3}$ cytoplasmic male sterility. The low levels of seed set on selfed $\mathrm{A}_{3} \mathrm{~F}_{2}$ individuals $(0.04 \%)$ as compared with $\mathrm{A}_{1} \mathrm{~F}_{2}$ individuals (74\%) is a clear indication of greatly reduced levels of viable pollen production from volunteer progeny of seed that escapes harvest in the cropping year. In field scale research and crop production, it is unlikely that all risks associated with new technologies can be completely eliminated. This research provides evidence that the risk of gene flow through sorghum pollen can be greatly reduced by using, at least in part, the technique described herein. In the event that transgenic sorghum is developed to the stage that field testing becomes appropriate, utilization of this technique should be considered in combination with cultural controls including spatial isolation, crop rotation or fallowing in subsequent cropping seasons, and herbicides active against sorghum to reduce risk of gene flow to weedy relatives.

\section{ACKNOWLEDGMENTS}

We thank D.R. Pring for technical advise and for providing control DNA.

\section{REFERENCES}

Atkins, R.E. 1983. Registration of 12 sorghum parental lines. Crop Sci. 24:1229.

Arriola, P.E., and N.C. Ellstrand. 1996. Crop-to-weed flow in the genus Sorghum (Poaceae): spontaneous interspecific hybridization between johnsongrass, Sorghum halepense, and crop sorghum, $S$. bicolor. Am. J. Bot. 83:1153-1160.

Arriola, P.E., and N.C. Ellstrand. 1997. Fitness of interspecific hybrids in the genus Sorghum: persistence of crop genes in wild populations. Ecol. Appl. 7:512-518.

Bergquist, R.R., D.S. Nubel, D.L. Thompson. 1998a. Production method for high-oil corn grain. U.S. Patent 5704 160. Date issued: 6 January, 1998.

Bergquist, R.R., D.S. Nubel, D.L. Thompson. 1998b. Production method for corn with enhanced quality grain traits. U.S. Patent 5 706 603. Date issued: 13 January, 1998.

Bosques-Vega, A., A. Sotomayor-Rios, S. Torres-Cardona, H.R. Perrerly, and K.F. Schertz. 1989. Maintainer and restorer reactions with $\mathrm{A}_{1}, \mathrm{~A}_{2}$, and $\mathrm{A}_{3}$ cytoplasms of lines from the sorghum conversion program. MP-1676. The Texas Agriculture Experiment Station, Texas A\&M University, College Station, TX.

Feil B., U. Weingartner, and P. Stamp. Controlling the release of pollen from genetically modified maize and increasing its grain yield by growing mixtures of male-sterile and male-fertile plants. Euphytica (in press).

Frederickson, D.E., P.G. Mantle, and W.A.J. De Milliano. 1991. Claviceps africana sp. nov.; the distinctive ergot pathogen of sorghum in Africa. Mycol. Res. 95:1101-1107.

Hoang-Tang, and G.H. Liang. 1988. The genomic relationship between cultivated sorghum [Sorghum bicolor (L.) Moench] and johnsongrass [S. Halepense (L.) Pers.]: A re-evaluation. Theor. Appl. Genet. 76:277-284.

Littell, R.C., G.A. Milliken, W.W. Stroup, and R.D. Wolfinger. 1996. SAS system for mixed models. SAS Institute Inc., Cary, NC, USA.

Pedersen, J.F., and J.J. Toy. 1997. Forage yield, quality, and fertility of sorghum $\times$ sudan grass hydrids in A1 and A3 cytoplasm. Crop Sci. 37:1973-1975.

Pedersen, J.F., and J.J. Toy. 1997. Registration of 43 sorghum genetic stocks in $\mathrm{A}_{2}, \mathrm{~A}_{3}$, and $\mathrm{A}_{4}$ cytoplasm. Crop Sci. 37:1412-1414.

Pedersen, J.F., J.J. Toy, and B.E. Johnson. 1998. Natural outcrossing of sorghum and sudangrass in the central Great Plains. Crop Sci. 38:937-939.

Pring, D.R., W. Chen, H.V. Tang, W. Howad, and F. Kempken. 1998. Interaction of mitochondrial RNA editing and nucleolytic processing in the restoration of male fertility in sorghum. Curr. Genet. 33:429-436.

Pring, D.R., H.V. Tang, W. Howad, and F. Kempken. 1999. A unique two-gene gametophytic male sterility system in sorghum involving a possible role of RNA editing in fertility restoration. J. Hered. 90:386-393.

Quinby, J.R., and K.F. Schertz. 1970. Sorghum genetics, breeding, and hybrid seed production. p. 73-117. In J.S. Wall and W.M. Ross (ed.) Sorghum production and utilization. AVI Publishing Company, Inc., Westport, CT.

Schertz, K.F. 1984. Registration of $\mathrm{A}_{3}$ Tx398 and $\mathrm{B}_{3}$ Tx398 male sterile and maintainer germplasm lines of sorghum. Crop Sci. 24:883.

Tang, H.V., D.R. Pring, L.C. Shaw, R.A. Salazar, F.R. Muza, B. Yan, and K.F. Schertz. 1996. Transcript processing internal to a mitochondrial open reading frame is correlated with fertility restoration in male-sterile sorghum. Plant J. 10:123-133.

Torres-Cardona, S., A. Sotomayor-Rios. A Quiles Belen, and K.F. Schertz. 1990. Fertility restoration to $\mathrm{A}_{1}, \mathrm{~A}_{2}$, and $\mathrm{A}_{3}$ cytoplasm systems of converted sorghum lines. MP-1721. The Texas Agriculture Experiment Station, Texas A\&M University, College Station, TX.

Weibel, D.E., J.B. Sieglinger, and F.F. Davies. 1984. Registration of fourteen sorghum parental lines. Crop Sci. 24:628. 